Dept. of Parasitology,

Fac. Vet. Med. Cairo University

\title{
ALTERATION IN SOME PHYSIOLOGICAL PARAMETERS AS A TOOL FOR DIAGNOSIS OF LEUCOCYTOZOON INFECTION IN DUCKS
}

(With 4 Tables and One Figure)

\section{By}

\author{
M.M. EL-BAHY and M.H. ABDEL-WAHAB*
}

* Animal Production Research Institute. (Seds, Beni-Suef), Egypt

(Received at 3/3/2009)

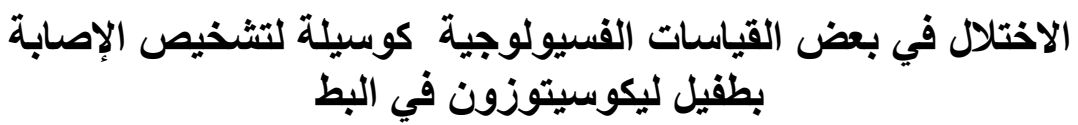

\section{محمد معوض الباهي ، مختار حسبن عبل الوهاب}

بتكر ار شكوى مربي البط بمركز طامية بمحافظة الفيوم من حدوث زيادة ملحوظة في نسب

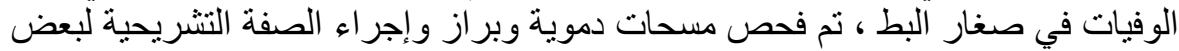

الطيور وقد تم تسجيل إصابات بعدد من الطفيليات شملت طفيل ليكوسيتوزون فئون سيموندي

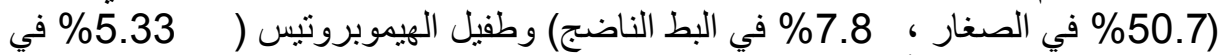

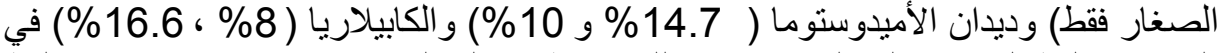

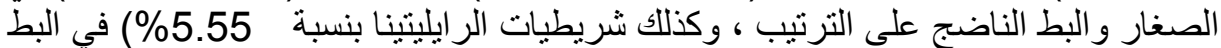

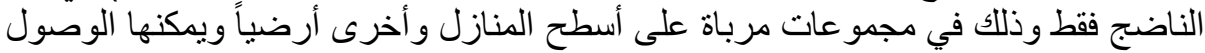

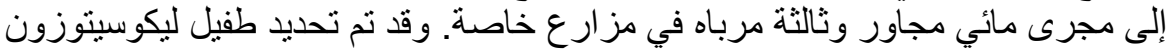

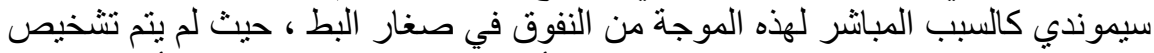

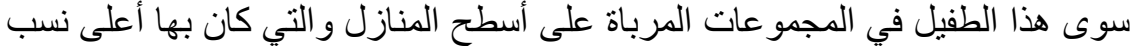

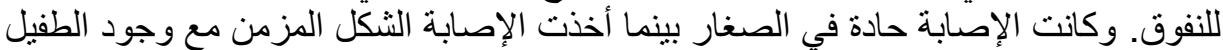

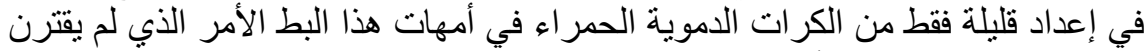
بحدوث وفيات في هذه الأمهات في نفس الحظائر. و وإيجاد وسيلة تمكن من التشخيص الته المبكر

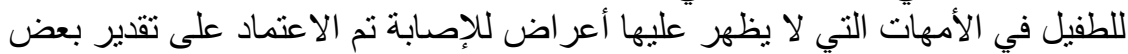
القياسات الفسيولوجية التي تساعد في نشخيص المرض في طور كمونه ، فقد وجد نقص

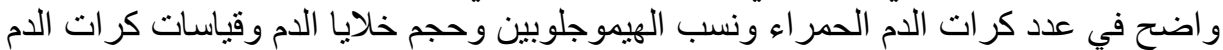

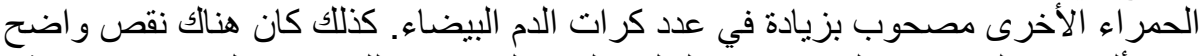

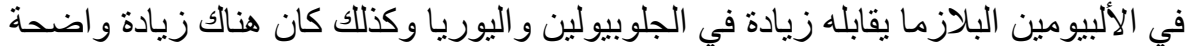

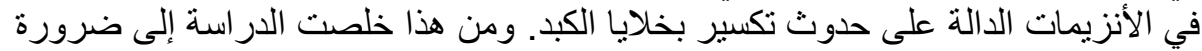

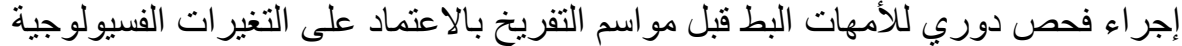
السابقة المصحوبة بعمل شر ائح دموية وذللك للتخلص من الأمهات المصابة فئ فبل فقس الصغخار وذلك في المناطق الموبو عة بهذا الطفيل. 


\section{SUMMARY}

The present study demonstrated Leucocytozoon simondi as the most common blood parasites causing large scale mortalities in duckling in special area in El-Fayoum Governorate, Egypt. Adult ducks in the farm carry the parasite in chronic form without clear symptoms associated with low number of infected cells in blood. The parasite cause alteration in some physiological parameters of the infected ducks include low RBCs count, PCV, Hb, increase in lymphocytes, eosinophil and monocytes, decrease in plasma Albumin accompanied by high globulin and urea. This was associated with elevation in AST \& ALT enzymes level. The study recommend regular estimation of these physiological parameters in mother ducks periodically as mean of risk assessment help in elimination of this disease from the farms via exclusions of these chronic infected ducks which serve as permanent source for this new infection in the farm.

Key words: Parasites, leucocytozoon, ducks.

\section{INTRODUCTION}

On the contrary to enormous data available on chicken, a little are available on ducks \& gees concerning parasitic diseases and its effect on some physiological parameters of infected birds. Severe mortalities usually recorded in duckling specially at the level of small breeders and usually no big interest was attended to clarify the exact cause of death. In the same time no more data are available concerning to the changes in physiological parameters in parasitic infected ducks that can facilitate early determination of suspected disease.

Concerning parasitic infection, Soulsby (1986) mentioned that there is several parasites can infect ducks inducing high morbidity (mainly Helminths infection) with low mortalities except in duckling, Myiasis induce sever mortalities in duckling. In the same time there are a few numbers of blood parasites can infect ducks but they induce large scale mortalities specially in duckling while the adult ducks can serve as chronic infected birds act as a permanent unapparent source for new infections in the farm. In this respect, Williams et al. (1977), recorded that examination of 60 mallard and 67 pintail ducks, during one year in Nigeria, revealed that $22(37 \%)$ of the mallards and $14(21 \%)$ of the pintails were infected with one or more species of hematozoa. Infections 
of L. simondi occurred more frequently (86\%) than Haemoproteus nettionis (22\%) in the infected birds. L. simondi is one of the most dangerous parasites of ducks it was associated with large scale mortality of ducks and geese, especially domestic ones as mentioned by Shutler, et al., 1999) and Bennett, et al. (1993).

Olayemi et al. (2002) estimate the plasma chemistry values in 14 healthy adult (50-80 weeks old) and 10 healthy young (8-10 weeks old) Nigerian ducks. They found that duckling had significantly greater (AST) and (ALT) values than the adult birds. (ALP), inorganic phosphate, bicarbonate (HCO3), sodium $(\mathrm{Na})$, potassium $(\mathrm{K})$ and chloride $(\mathrm{Cl})$ levels in the young bird were not significantly different from those of the adult duck. The total protein, albumin, globulin, urea and creatinine values were also similar in the young and adult birds.

The same authors in (2003) studied the effect of ducks age on some physiological parameters include white blood cell (WBC), plasma volume and blood volume in healthy adult (52-80 weeks old) and healthy young (8-10 weeks old) Nigerian ducks (Anas platyrhynchos). They found that mean total WBC, heterophil, lymphocyte, eosinophil and monocyte counts in the adult duck were 10.42, 4.22, 5.93, 0.09 and $0.17 \times 10^{9} / \mathrm{L}$, respectively. They concluded that these counts in adult birds were similar to the values in young ducks.

Olayemi, et al. (2006) compared some parameters of the Nigerian dove with that of Nigerian duck and mentioned that the ducks had significantly higher mean corpuscular volume, total white blood counts, plasma urea, total protein and globulin, but significantly lower red blood cell counts, haemoglobin concentration, mean corpuscular hemoglobin concentration, plasma potassium and albumin / globulin ratio than the Nigerian laughing dove. However, the packed cell volume $(\mathrm{PCV})$, mean corpuscular haemoglobin $(\mathrm{MCH})$, plasma sodium, creatinine and albumin were similar in the two species of bird with no significant sex differences in all the parameters studied.

In the present study a complain of large percentage of mortalities in duckling was recorded in several ducks breeding farmers house in Tamia, Fayoum, Egypt. Post-mortem examination did not detect clear cause except slight enlargement in liver and spleen in some birds only. Samples were collected from the other living birds in the same houses in order to identified the exact cause of death. Special interest was focused on studying some physiological changes that can facilitate early diagnosis of this type of infection before induction of mortalities. 


\section{MATERIALS and METHODS}

Birds: During 6 months (December 2004 - May, 2005) representing number of birds (as in table 1) were selected for the study from 4 different complained ducks breeding places. This include two farmer houses (G1 \& G2) (55 bird), birds in this system exposed freely to other wild birds. The $3^{\text {rd }}$ group is 20 sample from another breeding system (G-3, ground breeding) where birds in this system move free around their breeding place and they can gate access to a neighbour water way and returns back. The last group of examined ducks are 100 sample from ducks reared in local farm permit free movement to birds but inside restricted area. Birds were divided into two age categories as unsexed duckling (6-10 weeks old) and old adults females ducks over 47 weeks old that reached to the end of the peak of egg production. Birds select to represent the group as morbid birds, diseased birds and apparently healthy birds.

All of these birds were examined parasitologically (feces \& blood), but physiological studies was applied on birds infected by Leucocytozoono only as well as on another 20 (10 duckling \& 10 old adults) healthy birds as control to the estimated parameters.

\section{Samples:}

\section{Fecal samples:}

Birds were kept in separate boxes for individual fecal sample collection for parasitological examination during the period of 4 weeks. They were given commercially available growers mash and water adlibitum during this period. Individual fecal samples were transferred in identified plastic bags and kept in refrigerator for parasitological examination. Post-mortem examination and sample collection were done on all died birds as will.

\section{Fecal examination:}

Determination to the different enteric parasites (helminthes and protozoa) was done using concentration flotation technique and the detected diagnostic stages were identified according to Soulsby (1986).

\section{Blood samples:}

Blood was obtained from the jugular vein of each bird into a bottle containing ethylene diamine tetra acetic acid (EDTA, $2 \mathrm{mg} / \mathrm{ml}$ of blood). For parasitological examination and differential leucocytic count, thin blood smears, made in duplicate, were fixed in methyle alcohol and stained with Giemsa stain (Soulsby, 1986 and Olayemi, 2003). 
Total WBCs count (x $\left.10^{3} / \mathrm{mm}^{3}\right)$ were done using haemocytometer according to Bauer (1970). Two-hundred white cells were counted from each blood smear. The percentage of each white cell type was calculated and multiplied by the total WBCs count to obtain the absolute count.

The heterophil / lymphocyte $(\mathrm{H} / \mathrm{L})$ ratios were calculated as: $\mathrm{H} / \mathrm{L}$ ratio $=$ Number of $\mathrm{H} /$ number of $\mathrm{L}$

Packed cell volume (PCV\%) was estimated using microhematocrite method and the RBCs count $\left(x 10^{6} / \mathrm{mm}^{3}\right)$ was estimated using haemocytometer method according to Bauer (1970). Mean corpuscular hemoglobin $(\mathrm{MCH})$. Mean corpuscular volume (MCV) and mean corpuscular hemoglobin concentration (MCHC) were calculated according to Mangrum (1975).

Blood samples were centrifuged at $3.000 \mathrm{G}$ for 10 minutes to separate plasma. Plasma sodium $(\mathrm{Na} \mathrm{mmol} / \mathrm{L})$ and potassium $(\mathrm{K}$ $\mathrm{mmol} / \mathrm{L}$ ) concentrations were determined according to Elveback (1970), while inorganic phosphate $(\mathrm{mg} / \mathrm{dl})$ was estimated according to Gomori (1942).

Total plasma protein $(\mathrm{g} / \mathrm{dl})$ was measured using commercial kits accoprding to the method of Cannon, et al. (1974). Plasma albumin content $(\mathrm{d} / \mathrm{dl})$ was estimated calorimetric using bromocresol green as described by Doumas et al. (1971). Globulin (g/dl) was obtained by subtracting the albumin from the total plasma protein. Albumin: globulin $(\mathrm{A} / \mathrm{G})$ ratio was calculated by dividing albumin $(\mathrm{g} / \mathrm{dl}) / \mathrm{globulin}(\mathrm{g} / \mathrm{dl})$.

Urea and creatinine were determined according to Work (1996). The levels of aspartate aminotransferase (AST), alanine aminotransferase (ALT) and alkaline phosphate (ALP) was determined according to Tietz, (1995).

Ten healthy unsexed duckling ( 8 weeks old) and another 10 adult (50-52 weeks old) female ducks free from parasitic infection were selected from other farm and used as uninfected control birds.

Statistical tests were carried out using Student's t-test.

\section{RESULTS}

Examination of stained blood smears and fecal samples from 75 unsexed duckling (6-10 weeks old) and 95 adult ducks (over 47 weeks old) in one locality in El-Fayoum Governorate, Egypt, after recording a high rate of mortalities in duckling in these site as in Table (1), revealed 
that 2 blood parasites were recorded include Leucocytozoon (Fig. 1a) $(50.7 \%$ and $7.8 \%)$ in duckling and ducks respectively and $5.33 \%$ infection by Haemoproteus species (Fig. 1b) in blood of duckling only.

Concerning enteric parasites, infection by two nematode species was recorded as Amidostomum species (14.7\% in duckling and $10 \%$ in adult) and Capllaria species as $8 \%$ and $16.6 \%$ in duckling and adults respectively. In the same time infection by tape worms was also recorded as Raillietina species mainly in adult ducks by a percentage of $5.55 \%$. No other infection by trematodes or enteric protozoa could be diagnosed in the examined birds as in Table (1).

Concerning the distributions of these parasites among the different examined groups, it was clear that birds breed on the roof were harbouring low number of parasites than that reared on the ground system. Birds in these groups (G1 and G2) were had a high rate of infection by Leucocytozoon only (Fig. 1), (80\% and 79\%) in duckling and $(40 \%$ and $30 \%)$ in adult ducks, and no other parasites could be detected in examination of the collected samples or even during P.M. examination. On the contrary of this, Haemoprtues infection was recorded in 4 birds from 10 duckling examined in G3, also nematode eggs (Amidostomum and Capillaria species) was recorded in 4 and 3 adult ducks in this group.

By the same way, birds reared in the farm (G4) showing infection by variety of the above parasites include Leucocytozoon in $30 \%$ of duckling, Amidostomum species in $27.5 \%$ in duckling and $8.4 \%$ in adults, Capillaria species in $15 \%$ and $20 \%$ in the above tow age subgroups and finally Cestoda infection in $8.33 \%$ of adult ducks in this farm as in Table (1).

This part of the study concluded presence of Leucocytozoon as the most common poarasite in these group of birds (the only parasite recorded in G1 and G2) and it can identified as the main cause of mortalities which estimated by the owner as $30-70 \%$ in these farms. For this reason, the second part of the study directed toward identification of special parameters that can be help in risk assessment to infection by leucocytozoon specially where it diagnosed as chronic infection in adult ducks without induction of sever mortalities in these farm.

Determination to the alteration of some physiological parameters as a result of leucocytozoon infection table (2-4) revealed that, the data in Table (2) demonstrate the haematological difference in blood cells between leucocytozoon infected and uninfected young and adult ducks. The data cleared that significance in the RBCs count in infected 
duckling than in adult birds in comparison with the control non-infected birds.

The same significance decrease was recorded also to PCV and $\mathrm{Hb}$ concentration. This RBCs changes demonstrated a condition of marked hemolytic anemia in duckling, while the condition did not tack the same picture in adult birds.

Concerning changes in WBCs, slight increase in total leucocytic count was recorded in both infected adult and young birds with significant increase in lymphocyte, eosinophil and decrease in Heterophil / lymphocyte ratio in comparison with the control noninfected birds, Monocytes, the condition which reflect as in Table (2).

Concerning to the effect of leucocytozoon infection on plasma electrolyte and some plasma enzyme levels, the data in Table (3) cleared that slight decrease in the different plasma electrolyte $(\mathrm{Na}, \mathrm{Cl}, \mathrm{K}, \mathrm{Ca}$ and inorganic phosphorus) could be recorded in infected birds. High significant deviation was recorded in liver enzymes (AST, ALT \& ALP), where they significantly increased $(\mathrm{P}<0.005)$ in infected duckling and adults specially for AST (GOT) and ALT (GPT) enzymes.

In the same time Leucocytozoon infection was affect also on plasma proteins and metabolite levels as shown in table (4). A significant decrease in albumine and significant increase in globulin, this was reflect marked deviation in albumin / globulin ratio in infected duckling and adult. This also was associated with increase in urea level in comparison with non-infected control ducks. 
Table 1: Different parasites diagnosed in the examined groups.

\begin{tabular}{|c|c|c|c|c|c|c|c|c|c|c|c|c|c|}
\hline \multirow{3}{*}{ 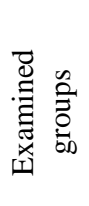 } & \multirow{3}{*}{$\begin{array}{l}\text { Source of } \\
\text { sample }\end{array}$} & \multirow{3}{*}{ Age groups } & \multirow{3}{*}{$\begin{array}{l}\text { Bird } \\
\text { No. }\end{array}$} & \multicolumn{4}{|c|}{ Blood parasites } & \multicolumn{6}{|c|}{ Enteric parasites } \\
\hline & & & & \multicolumn{2}{|c|}{ Haemorprotues } & \multicolumn{2}{|c|}{ Leucocytozoon } & \multicolumn{2}{|c|}{$\begin{array}{l}\text { Amidostomum } \\
\text { anseris }\end{array}$} & \multicolumn{2}{|c|}{ Capillaria spp. } & \multicolumn{2}{|c|}{ Cestoda worms } \\
\hline & & & & $\begin{array}{l}\text { No. } \\
\text { infect }\end{array}$ & $\%$ & $\begin{array}{l}\text { No. } \\
\text { infect }\end{array}$ & $\%$ & $\begin{array}{l}\text { No. } \\
\text { infect }\end{array}$ & $\%$ & $\begin{array}{l}\text { No. } \\
\text { infect }\end{array}$ & $\%$ & $\begin{array}{l}\text { No. } \\
\text { infect }\end{array}$ & $\%$ \\
\hline \multirow{2}{*}{ G1 } & \multirow{2}{*}{$\begin{array}{c}\text { Farmer house } \\
\text { (Roof } \\
\text { breeding) }\end{array}$} & Duckling* & 15 & 0 & 0 & 12 & $80 *$ & 0 & - & 0 & - & 0 & - \\
\hline & & Adult $* *$ & 10 & 0 & 0 & 4 & $40 \%$ & 0 & - & 0 & - & 0 & - \\
\hline \multirow{2}{*}{$\mathrm{G} 2$} & \multirow{2}{*}{$\begin{array}{c}\text { Farmer house } \\
\text { (Roof } \\
\text { breeding) }\end{array}$} & Duckling* & 20 & 0 & 0 & 14 & $70^{*}$ & 0 & - & 0 & - & 0 & - \\
\hline & & Adult $* *$ & 10 & 0 & 0 & 3 & 30 & 0 & - & 0 & - & 0 & - \\
\hline \multirow{2}{*}{ G3 } & \multirow{2}{*}{$\begin{array}{l}\text { Farmer house } \\
\text { (Roof } \\
\text { breeding) }\end{array}$} & Duckling* & 10 & 4 & $40 \%$ & 0 & 0 & 0 & - & 0 & - & 0 & - \\
\hline & & Adult $* *$ & 10 & 0 & 0 & 0 & 0 & 4 & $40 \%$ & 3 & $30 \%$ & 0 & - \\
\hline \multirow{2}{*}{ G4 } & \multirow{2}{*}{ Local farm } & Duckling* & 40 & 0 & 0 & 12 & $30 \%$ & 11 & 27.5 & 6 & 15 & 0 & - \\
\hline & & Adult $* *$ & 60 & 0 & 0 & 0 & 0 & 5 & 8.4 & 12 & 20 & 5 & 8.33 \\
\hline & \multirow{2}{*}{ Total } & Duckling* & 75 & 4 & 5.33 & 38 & 50.7 & 11 & 14.7 & 6 & $8 \%$ & - & - \\
\hline & & Adult ** & 90 & 0 & - & 7 & $7.8 \%$ & 9 & 10 & 15 & 16.6 & 5 & 5.55 \\
\hline
\end{tabular}

* Duckling unsexed young of 6-10 weeks old

** Adult, ducks over 47 weeks old (post peak of egg production) 
Table 2: Effect of Leucocytozoon infection on different blood cells of infected birds $(n=10)$.

\begin{tabular}{|c|c|c|c|c|c|}
\hline & \multicolumn{2}{|c|}{$\begin{array}{c}\text { Duckling } \\
\text { (6-10 weeks old })\end{array}$} & \multicolumn{2}{|c|}{$\begin{array}{c}\text { Adult } \\
\text { (0ver } 47 \text { weeks old) }\end{array}$} \\
\hline & & $\begin{array}{l}\text { Control non } \\
\text { infected } \\
\text { birds }\end{array}$ & $\begin{array}{l}\text { Infected } \\
\text { birds }\end{array}$ & $\begin{array}{l}\text { Control } \\
\text { non } \\
\text { infected } \\
\text { birds }\end{array}$ & $\begin{array}{c}\text { Infected } \\
\text { birds }\end{array}$ \\
\hline \multicolumn{2}{|l|}{$\mathrm{RBCs}\left(\mathrm{x} 10^{12} / \mathrm{L}\right)$} & $2.35 \pm 0.41$ & $\begin{array}{c}1.66 \pm 5.8 \\
*\end{array}$ & $2.28 \pm 0.66$ & $2.19 \pm 0.57$ \\
\hline \multicolumn{2}{|l|}{$\operatorname{PCV}(\%)$} & $40.51 \pm 4.3$ & $\begin{array}{c}25.7 \pm 5.4 \\
*\end{array}$ & $39.8 \pm 3.8$ & $37.5 \pm 2.7$ \\
\hline \multicolumn{2}{|l|}{$\mathrm{Hb}(\mathrm{g} / \mathrm{l})$} & $99.8 \pm 9.7$ & $\begin{array}{c}62.1 \pm 3.5 \\
*\end{array}$ & $122.2 \pm 4.3$ & $111.3 \pm 1.8$ \\
\hline \multicolumn{2}{|l|}{$\mathrm{MCH}(\mathrm{pg})$} & $42.46 \pm 5.8$ & $37.4 \pm 0.8$ & $53.59 \pm 1.6$ & $50.82 \pm 0.8$ \\
\hline \multicolumn{2}{|l|}{$\mathrm{MCHC}(\mathrm{g} / \mathrm{dl})$} & $24.6 \pm 2.9$ & $\begin{array}{c}24.16 \pm \\
0.8\end{array}$ & $30.7 \pm 0.3$ & $29.68 \pm 0.7$ \\
\hline \multicolumn{2}{|l|}{ MCV (fl) } & $172.38 \pm 0.6$ & $\begin{array}{c}154.8 \pm \\
0.2\end{array}$ & $\begin{array}{c}174.56 \pm \\
0.3\end{array}$ & $\begin{array}{c}171.23 \pm \\
0.6\end{array}$ \\
\hline \multicolumn{2}{|l|}{ Total WBC (x 109/1) } & $12.09 \pm 4.0$ & $\begin{array}{c}12.52 \pm \\
1.4\end{array}$ & $11.22 \pm 1.6$ & $11.52 \pm 2.1$ \\
\hline \multirow[b]{2}{*}{ Heterophil (x 10/l) } & No. & $5.14 \pm 2.1$ & $4.63 \pm 3.1$ & $4.72 \pm 1.6$ & $4.56 \pm 1.5$ \\
\hline & $\%$ & $46.44 \pm 3.3$ & $\begin{array}{c}44.67 \pm \\
5.1\end{array}$ & $41.1 \pm 8.5$ & $41.2 \pm 3.5$ \\
\hline \multirow[t]{2}{*}{ Lymphocyte (x 109/1) } & No. & $5.92 \pm 3.4$ & $\begin{array}{c}9.41 \pm 3.4 \\
*\end{array}$ & $6.11 \pm 2.1$ & $7.33 \pm 2.8$ \\
\hline & $\%$ & $50.2 \pm 11.2$ & $51.3 \pm 8.3$ & $56.6 \pm 8.2$ & $56.4 \pm 7.7$ \\
\hline \multirow[t]{2}{*}{ Eosinophil (x 109l) } & No. & $0.09 \pm 0.1$ & $\begin{array}{c}0.84 \pm 0.8 \\
*\end{array}$ & $0.11 \pm 0.2$ & $0.32 \pm 0.4$ \\
\hline & $\%$ & $0.85 \pm 0.7$ & $1.3 \pm 0.5$ & $0.84 \pm 1.1$ & $0.91 \pm 0.8$ \\
\hline \multirow[t]{2}{*}{ Monocyte (x 109/1) } & No. & $0.41 \pm 0.31$ & $\begin{array}{c}0.96 \pm 0.7 \\
*\end{array}$ & $0.22 \pm 0.33$ & $0.6 \pm 0.5$ \\
\hline & $\%$ & $2.51 \pm 0.31$ & $2.73 \pm 0.3$ & $1.46 \pm 1.33$ & $1.49 \pm 0.41$ \\
\hline \multicolumn{2}{|c|}{$\begin{array}{l}\text { Heterophil / lymphocyte } \\
\text { ratio }\end{array}$} & $1.10 \pm 0.31$ & $\begin{array}{c}0.61 \pm \\
0.22\end{array}$ & $0.82 \pm 0.33$ & $0.74 \pm 0.32$ \\
\hline
\end{tabular}

$* \mathrm{P}<0.05$ 

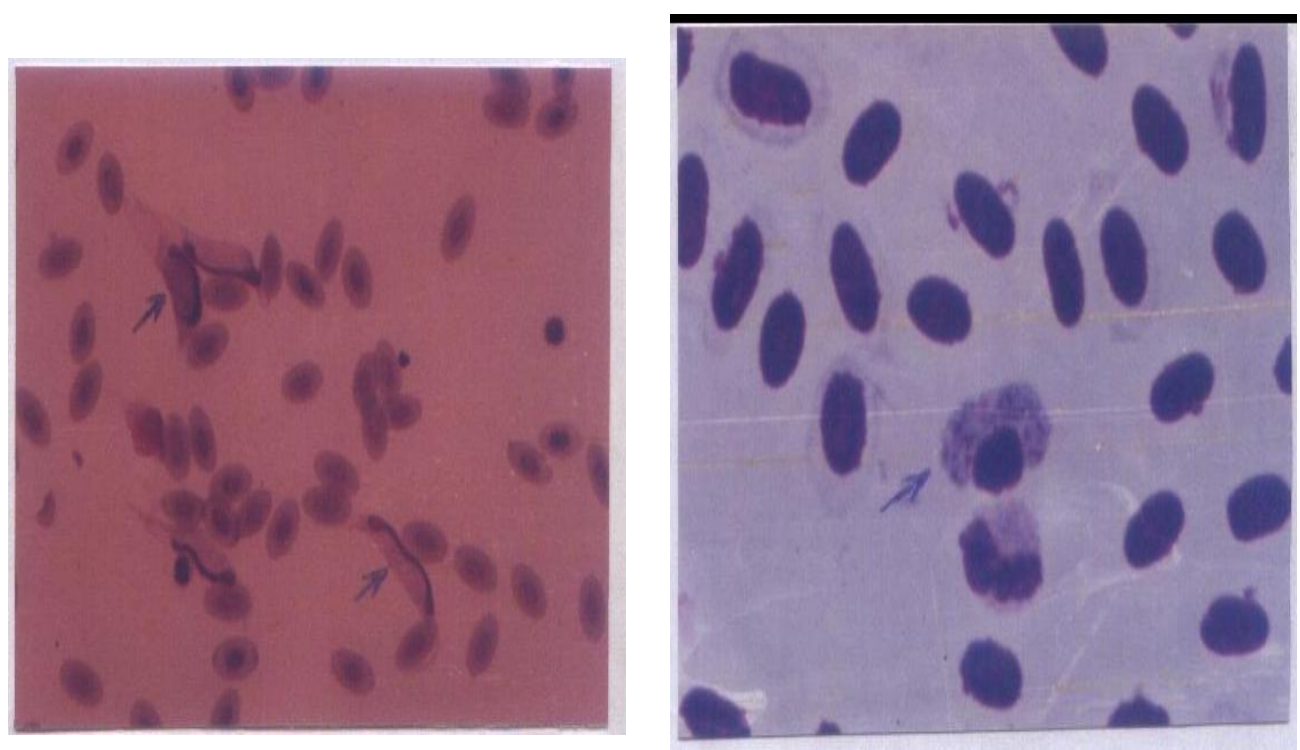

Fig. 1: Blood film of infected ducks showing Leucocytozoon simondi

Table 3: Effect of Leucocytozoon infection on plasma electrolyte and enzyme levels (mean \pm SD) in infected ducks $(n=10)$.

\begin{tabular}{|l|c|c|c|c|}
\hline \multirow{2}{*}{} & \multicolumn{2}{|c|}{$\begin{array}{c}\text { Duckling } \\
(6-10 \text { weeks old) }\end{array}$} & \multicolumn{2}{c|}{ (0ver 47 weeks old) } \\
\cline { 2 - 5 } & $\begin{array}{c}\text { Control non } \\
\text { infected birds }\end{array}$ & Infected birds & $\begin{array}{c}\text { Control non } \\
\text { infected birds }\end{array}$ & Infected birds \\
\hline $\mathrm{Na} \mathrm{(mmol} \mathrm{/} \mathrm{)}$ & $141.814 \pm 5.411$ & $138.612 \pm 2.421$ & $144.622 \pm 3.631$ & $141.721 \pm 3.114$ \\
\hline $\mathrm{Cl}(\mathrm{mmol} / \mathrm{l})$ & $107.723 \pm 2.612$ & $103.321 \pm 3.322$ & $110.342 \pm 1.742$ & $105.241 \pm 3.215$ \\
\hline $\mathrm{K}(\mathrm{mmol} / \mathrm{dl})$ & $5.717 \pm 1.811$ & $5.273 \pm 0.821$ & $6.131 \pm 1.223$ & $5.991 \pm 0.212$ \\
\hline $\mathrm{Ca}(\mathrm{mg} / \mathrm{dl})$ & $9.584 \pm 1.493$ & $8.18 \pm 1.423$ & $10.32 \pm 1.374$ & $9.225 \pm 1.321$ \\
\hline $\begin{array}{l}\text { Inorganic } \\
\text { phosphate } \\
(\mathrm{mg} / \mathrm{dl})\end{array}$ & $5.113 \pm 0.773$ & $4.812 \pm 1.612$ & $4.822 \pm 0.721$ & $4.141 \pm 1.211$ \\
\hline ALP (i.u. / 1) & $74.262 \pm 5.141$ & $92.633 \pm 4.265$ & $81.552 \pm 4.633$ & $96.821 \pm 8.245$ \\
\hline AST (i.u. / l) & $54.835 \pm 8.521$ & $76.615 \pm 5.813$ & $51.521 \pm 6.224$ & $79.111 \pm 8.241$ \\
\hline ALT (i.u. / l) & $22.311 \pm 2.385$ & $89.371 \pm 5.431 * *$ & $13.633 \pm 4.351$ & $56.831 \pm 5.221 *$ \\
\hline
\end{tabular}

Significant at $* \mathrm{P}<0.05, \quad * * \mathrm{P}<0.005$ 
Table 4: Effect of Leucocytozoon infection on plasma electrolyte and enzyme levels (mean $\pm S D)$ in infected ducks $(n=10)$.

\begin{tabular}{|l|c|c|c|c|}
\hline \multirow{2}{*}{} & \multicolumn{2}{|c|}{$\begin{array}{c}\text { Duckling } \\
(6-10 \text { weeks old) }\end{array}$} & \multicolumn{2}{c|}{ (0ver 47 weeks old) } \\
\cline { 2 - 5 } & $\begin{array}{c}\text { Control non } \\
\text { infected birds }\end{array}$ & Infected birds & $\begin{array}{c}\text { Control non } \\
\text { infected birds }\end{array}$ & Infected birds \\
\hline Total protein (g/dl) & $3.792 \pm 0.322$ & $5.385 \pm 0.13$ & $3.511 \pm 0.32$ & $5.751 \pm 0.221$ \\
\hline Albumin (g/dl) & $1.470 \pm 0.215$ & $1.153 \pm 0.331^{*}$ & $1.331 \pm 0.241$ & $1.011 \pm 0.441^{*}$ \\
\hline Globulin (g/dl) & $2.322 \pm 0.313$ & $4.232 \pm 0.410^{*}$ & $2.180 \pm 0.33$ & $4.740 \pm 0.453 *$ \\
\hline $\begin{array}{l}\text { Albumin/globulin } \\
\text { ratio }\end{array}$ & $0.633 \pm 0.423$ & $0.272 \pm 0.521^{*}$ & $0.610 \pm 0.524$ & $0.210 \pm 0.611^{*}$ \\
\hline Urea (mg/dl) & $22.323 \pm 9.512$ & $29.435 \pm 7.512$ & $23.412 \pm 10.322$ & $26.621 \pm 8.411$ \\
\hline Creatinine (mg/dl) & $0.146 \pm 0.233$ & $0.163 \pm 0.254$ & $0.265 \pm 0.482$ & $0.385 \pm 0.535$ \\
\hline
\end{tabular}

Significant at $* \mathrm{P}<0.05$

\section{DISCUSSION}

While duck live in the same habitate as the other birds, they still have low parasitic fauna in comparison with other birds, this fact was agreed with that mentioned with Orajaka and Nweze (1991) where he failed to found blood parasites in geese, ducks and guinea fowls in examined sample from Anambra state, Nigeria. Also little is published concerning the physiological alteration in some physiological parameters of ducks as a result of special parasitic infection.

The present study follow up the cause of large scale mortalities in duckling in El-Fayoum Governorate, Egypt during a short period as scope about the condition in this bird type. The study determine infection by two blood parasites as $L$. simondi species and Haemoprotusa species and 3 helminthes parasites in alimentary tracts. Leucocytozoon and Amidostomum species are known to cause wide scale mortalities specially in duckling, while the adult ducks can serve the infection in chronic froms, this was agreed with Soulsby, (1986) and Shutler, et al. (1999). Also Bennett, et al. (1993), which identify L. simondi as implicated in heavy mortality in Anatids specially in juvenile birds.

L. simondi and plasmodium was transmitted via blood sucking insects (black fly and mosquitoes) while Amidostomum did not need an intermediate hosts, the matter which facilitate arrival of both parasites to 
duckling if they are close to source of infection. Presence of the same infection in chronic form in adult birds prefer this permanent source of infection in the same farm.

The previous part of the study demonstrated $L$. simondi as the most common parasites diagnosed in the above groups of ducks and it can be incriminated as it is the cause of the recorded mortalities. This also supported by presence of chronic infection in adult ducks. Increasing rate of infection and mortalities in birds breed on roof, may be due to their exposure to the transmitting vector more than the group reared in the ground.

Presence of ducks with single type of parasitic infection (as that recorded for $L$. simondi on roof breeding groups of ducks) is a good chance in order to identify some physiological parameters which can facilitate assessment of infection in chronic infected birds for this fatal parasites which usually present without easily detected forms in general circulation.

Estimation of some physiological parameters in L. simondi infected ducks revealed more than one characteristic signal help in identification of the chronic infected ducks which can act as a future source of the disease to the young birds.

Infection by $L$. simondi cause sever anemia in ducks (Kocan and Clark, 1966), this was comment on the significant decrease in the number of RBCs, $\mathrm{Hb}, \mathrm{PCV}$ and the other related indices in comparison with the control non-infected birds. This anemia due to development of the parasites gametocytes in RBCs (Bates, 2004). The condition was more sever in duckling than in adults. This came in agreement with Kocan and Clark (1966) and Kim-Bates (2004). The recorded parameters in the control non-infected birds was agreed with that previously mentioned by El-Ghamry (2004) and El-Kaiaty et al. (2004) while absence of difference between duckling and adults was agreed with Maxwell et al. (1990) and Olayemi et al. (2003).

According to Soulsby (1986) and Kim-Bates (2004), L. simondi developed primary in liver then migrate to RBCs this fact can be clearly comment on the most recorded alteration in the blood and plasma composition. This include the increase in Eosinopihl and as well as the enlargement in the liver and spleen. The dangerous effect of the parasite appear as more diagnostic symptoms in chronic infected adult birds where it induce high elevation in the liver enzyme level in plasma (AST $\&$ ALT). the difference in the level of these parameters in duckling than in adults was previously mentioned by Olayemi et al. (2002) and El- 
Kaiaty et al. (2004) as duckling had significantly greater (AST) and (ALT) values than the adult birds. They added that the alkaline phosphatase (ALP), inorganic phosphate, sodium $(\mathrm{Na})$, potassium $(\mathrm{K})$ and chloride $(\mathrm{Cl})$ levels in the young bird were not significantly different from those of the adult duck. The total protein, albumin, globulin, urea and creatinine values were also similar in the young and adult birds.

The study recorded sever decrease in Albumin level accompanied with increase in globulin level this demonstrate the adverse destruction's which occurs in the liver of the infected birds.

All these parameters demonstrated that Leucocytozoon appear as the main cause of large scale mortalities recorded in the previous farms where this was agreed with Kim-Bates (2004).

For conclusion in order to achieve risk assessment for possibility of future infection of ducks farm by a dangerous insecta transmitting parasite like leucocytozoon, the study advise by periodical evaluation of some parameters in the adult ducks which usually carry the parasite in chronic form, with few stages in RBCs. Presence of haemolytic anemia parameters (low RBCs count, low PCV and low $\mathrm{Hb} \%$ ) accompanied by high levels of AST and ALT decreased albumin / globulin ratio in ducks, these facts could be considered as clear guide help in suspect presence of leucocytozoon infection in the farm.

\section{REFERENCES}

Bauer, J.D. (1970): Numerical evaluation of red blood, white blood cells and platelts, art III, haematology gradwoll, clinical laboratory methods and diagnosis (Frankel, S.; Reitman, S. and Somen Wirth, A. (1) $7^{\text {th }}$ ed 489. The C.V. Mosby Co., Saint Louis.

Bennett, G.; Peirce, M.A. and Ashford, R.W. (1993): Avian haematozoa: mortality and pathogenicity . J. Nat. His. 27: 993-1001.

Cannon, D.C.; Olitby, I. and Inkept, J.A. (1974): Proteins in clinical chemistry, principles and techniques, Hyper and Row, Publishers, Hagerstown, Maryland, New York, $2^{\text {nd }}$ ed. P. 421.

Doumas, B.T.; Watson, W. and Biggs, H.G. (1971): Albumin standards and the measurement of serum albumin with bromocrosol green. Clin. Chim. Acta, 31: 87-96.

El-Ghamry, A.A. (2004): Effect of some medical plants and live yeast as feed additives on the productive performance of Muscovi ducks. Egypt. Pul. Sci. 24 (III) : 639-653. 
El-Kaiaty, A.M.; Faten, A.A.; Ibrahim and Nemarallah G.M. Ali (2004): Response in growth, blood constituents, physiological functions and immune responses due to Iodide injection of growing Muscovi ducks. Egypt. Pult. Sci. , 24 (IV): 787-805.

Elveback, N.W. (1970): Fundamental of clinical chemistry. W.B. Saunders, Philapdelphia.

Gomori, G. (1942): A modification of the calorimetric deyermination of phosphorus for use with the photoelectric colorimeter. J. Lab. Clin. Med. 27: 955-976.

Kim-Bates (2004): Leucocytozoon simoindi, Protozoal disease, Google, Coccidia and leucocytozoon.htm.

Kocan, R.M. and Clark D.T. (1966): Anemia in ducks infected with Leucocytozoon simoindi. J. Protozool. 13: 465-468.

Mangrum, R.E. (1975): Manual of haematology Reston publishing Co. Inc. Reston Virginia, USA.

Maxwell, M.H.; Robertson, G.W.; Spence, S. and McCorquodale (1990): Comparison of haematological values in restricted and adlibitum feed domestic fowls: WBCsa nd thrombocytes. Brit. Poult. Sci. 31: 399-405.

Olayemi, F.O.; Oyewale, J.O. and Omolewa, O.F. (2002): Plasma chemistry values in the young and adult Nigerian duck. Bll. Anim. Hlth. Prod. Afri. 50: 67-71.

Olayemi, O.F.; Johnson Oyewale, J.; Samson, R.N. and Olayinka, O. (2003): Comparative assessment of the white blood cell values, plasma volume and blood volume in the young and adult Nigerian duck (Anas platyrhynchos). Vet. Arhiv, 73 (5): 271276.

Olayemi, O.F.; Ernest, O.O.; Olusegun A. and Fagbohun, L. (2006): Haematological and plasma biochemical parameters of the Nigerian laughing dove Streptopelia senegalensis) and the Nigerian duck (Anas platyrhynchos). Vet Arhiv. 76: 145-151.

Oragaka, L.J. and Nweze, L.C. (1991): Prevalence of blood protozoan parasites of avian species in Nsukka area of Anambra State, Nigeria. Beitr Trop Landwirtsch Veterinarmed, 29 (1): 91-95.

Shutler, D.C.; Davison Ankney and Adele Mullie (1999): Effects of the blood parasite Lucocytozoon simondi on growth rates of anatid ducklings. Can. J. Zool. 77 (10: 1573-1578. 
Soulsby, E.J. (1986): Helminths, Arthropods and Protozoa of domesticated animals (Textbook). Williams and Wilkins Company, Baltimore $6^{\text {th }}$ ed. Tindal and Cassel Ltd, 7-8 Henrietta street London $\mathrm{Wc2}$.

Tietz, N.W. (1995): Clinical guide to laboratory tests. $3^{\text {rd }}$ ed. Saunder W.B. Philadelphia USA.

Williams, N.A.; Calverley, B.K. and Mahrt, J.L. (1997): Blood parasites of mallard and pintail ducks from central Alberta and the Mackenize Delta, Northwest Territories ....

Work, T.M. (1996): Weights, haematology and serum chemistry of seven species of free ranging tropical pelagic seabirds. J. Wild. Dis. 32: 643-657. J. of Wildlife Dis. 13 (3): 226-229. 